\title{
Reproductive biological traits of the goby Stigmatogobius pleurostigma (Bleeker, 1849) from the Mekong Delta, Vietnam
}

\author{
Q. M. DINH AND N. T. T. TRAN \\ Department of Biology, School of Education, Can Tho University, 3/2 Street, Xuan Khanh Ward, Ninh Kieu District \\ Can Tho - 900 000, Vietnam \\ e-mail:dmquang@ctu.edu.vn
}

\section{ABSTRACT}

Stigmatogobius pleurostigma (Bleeker, 1849) is an estuarine species of goby and widely distributed in Asian regions, but very little is known about the reproductive biological traits of this species. The present study was conducted along the coastline of the Mekong Delta, Vietnam from November 2015 to October 2016 to elucidate basic reproductive parameters of the species. A total of 155 fish ( 96 females and 59 males) were collected every month using fixed bag nets from the mangrove forests in the study area. Data analysis showed that the sex ratio is significantly different from 1:1. This gobiid species is an iteroparous fish spawning from March to November in the study region as deduced from the appearance of mature and ripe ovaries during this period. The length at first maturity was estimated as $4.14 \mathrm{~cm}$ in total length and absolute fecundity was found to be quite high (3,100-5,650 eggs) with a strong positive relationship with fish length and weight. The results obtained in this study contribute to the knowledge on the reproductive biology as well as stock status of the species.

Keywords: Absolute fecundity, Gonadosomatic index, Length at first maturity, Spawning season, Stigmatogobius pleugostigma

\section{Introduction}

Knowledge of reproductive biology of fish species has an important role in fishery management (Miller, 1984; Komolafe and Arawomo, 2007). Wootton (1990) reported that semelparity and iteroparity (synchronous and asynchronous patterns) were the two main reproductive strategies of fish. The iteroparous strategy is common for numerous gobies (Miller, 1984). Fish fecundity and size at first maturity are used for recruitment and abundance estimation (Kovacic, 2001) and fish stock management (Fontoura et al., 2009; Teichert et al., 2014). However, little is known about the reproductive biology of gobiid species inhabiting the Mekong Delta in Vietam where they have high species diversity and are being overexploited (Trinh and Tran, 2012). Therefore, there is a need to generate in depth knowledge on the reproductive biological traits of gobiids to understand their recruitment strategies in estuaries.

Stigmatogobius pleurostigma (Bleeker 1849) (Family : Gobiidae) is a small gobiid species with an elongated body (Larson, 2005) and is widely distributed from freshwater to brackishwater in South-east Asia including Vietnam (Larson, 2005; Froese and Pauly, 2017). The Stigmatogobius genus comprises seven species including $S$. borneensis, S. elegans, S. minima, S. pleurostigma, S. sadanundio, S. sella and S. signifer
(Larson, 2005) but only S. pleurostigma is recorded in the Mekong Delta, Vietnam (Tran et al., 2013). This species is a targeted species for fishing and displays negative allometric growth (Dinh, 2017), but there is no information on its reproductive biological traits. This study, therefore, aims at providing information on certain aspects of reproductive biology of this gobiid species such as sex ratio, gonadal development, spawning strategy and season, size at first maturity, fecundity and egg size which could contribute towards resource assessment and management of the species in Mekong Delta.

\section{Materials and methods}

Study site and fish collection

This study was carried out at Tran De, Soc Trang Province $\left(9^{\circ} 28^{\prime} 47.41^{\prime \prime} \mathrm{N} ; 106^{\circ} 12^{\prime} 25.96^{\prime \prime} \mathrm{E}\right)$ which is fringed by mangrove forest with a large mudflat and semi-diurnal tide. In the dry season (January-May), it rarely rains whereas heavy rains (approximately $400 \mathrm{~mm}$ per month) appear in the wet season (June-December). The mean annual temperature is $\sim 27^{\circ} \mathrm{C}$. The natural environmental conditions are typical for the Mekong Delta, Vietnam (Le et al., 2006).

Fish specimens were collected every month from the mangrove forest regions using fixed bag nets with $1.5 \mathrm{~cm}$ mesh size in the cod-end from November 2015 to October 
2016. During high tide, three nets were set, each at a distance of $250 \mathrm{~m}$ from the other for 2-3 $\mathrm{h}$ and during ebb tide they were retrieved to collect fish. After collection, fish were sexed by examination of genital papilla morphology as described by Dinh (2017) and identified based on their external description and classification (Tran et al., 2013). Fish were then anaesthetised using benzocaine and preserved in $5 \%$ formalin before transporting to the laboratory.

\section{Fish analysis}

In the laboratory, fish specimens were weighed to the nearest $0.01 \mathrm{~g}$ and measured in length to the nearest $0.1 \mathrm{~cm}$ before removing ovaries and testes. Gonads were then classified visually into six maturation stages based on the criteria description for Gobius niger by Vesey and Langford (1985). Fish length at first maturity $\left(\mathrm{L}_{\mathrm{m}}\right)$ was estimated using the logistic curve as $\mathrm{P}=1 /(1+\exp [-\mathrm{r}$ $\left.\left(T L-L_{m}\right)\right]$ ), where, $P$ is the proportion of mature individuals in a length class; $\mathrm{L}_{\mathrm{m}}$ is the length with $50 \%$ of fish reaching sexual maturity, and $\mathrm{r}$ is a model parameter (Zar, 1999). All eggs of mature (stage IV) and ripe (stage V) ovaries were placed and counted in a petri dish to determine the absolute fecundity based on the method of Dinh et al. (2016). The Motic Image Pro Plus v.2 software was used to determine the diameter of 30 randomly selected oocytes at each oocyte stage to estimate mean oocyte diameter per ovarian stage (Dinh et al., 2016). This software was also used to measure the width of ovaries and testes from the microscopic images. The ovaries and testis were examined histologically as per Carleton et al. (1980). For this the gonads were fixed in Bouin's solution for $24 \mathrm{~h}$, then the gonads were washed and stored in $70 \%$ alcohol until further processing. The fixed tissues were then dehydrated in ascending series of alcohol, embedded in paraffin wax, trimmed and $6 \mu \mathrm{m}$ thick sections were cut using a microtome. The thin sections were finally mounted on a glass slide for staining with Mayer's haematoxylin and eosin. The developmental stages of the oocytes and spermatocytes were then described following Yamamoto (1956) and Yamazaki (1965).

\section{Data analysis}

The differences in males and females between the dry (January-May) and the wet (June-December) seasons were examined by $\chi^{2}$ test. The variation of oocyte diameters between ovarian development stages was tested by one-way ANOVA. Logarithmic regression was used to examine the relationships between fish total length and weight to fecundity (Metin et al., 2011). All statistical analysis was carried out in SPSS software v.21 at a significance level of 5\%.

\section{Results}

Sex ratio, length at first maturity and fecundity

A total of 155 fish (96 females and 59 males, Table 1) were collected for the present study during the wet and dry seasons. The female to male ratios of S. pleugostigma were significantly different from the ratio of 1:1 within the dry (21 females and 12 males) and the wet seasons (75 females and 45 males, $\chi^{2}, p<0.05$ in all cases). In this study $S$. pleurostigma was found to attain $4.14 \mathrm{~cm}$ in total length at first sexual maturity (Fig. 1). The absolute fecundity of $S$. pleurostigma ranged from 3,100 eggs ( $4.6 \mathrm{~cm}$ in length and $1.18 \mathrm{~g}$ in weight) to 5,650 eggs ( $5.6 \mathrm{~cm}$ in length and $2.34 \mathrm{~g}$ in weight). This goby displayed a positive relationship between absolute fecundity with total length of fish (Fig. 2a) and body weight (Fig. 2b).

Table 1. Number of Stigmatogobius pleurostigma caught from the study site over time

\begin{tabular}{lll}
\hline Sampling time & No. of female & No. of male \\
\hline Nov.15 & 4 & 7 \\
Dec.15 & 2 & 5 \\
Jan.16 & 2 & 2 \\
Feb.16 & 6 & 2 \\
Mar.16 & 6 & 1 \\
Apr.16 & 3 & 1 \\
May16 & 4 & 6 \\
Jun.16 & 4 & 3 \\
Jul.16 & 23 & 19 \\
Aug.16 & 25 & 1 \\
Sep.16 & 8 & 3 \\
Oct.16 & 9 & 9 \\
Total & 96 & 59 \\
\hline
\end{tabular}

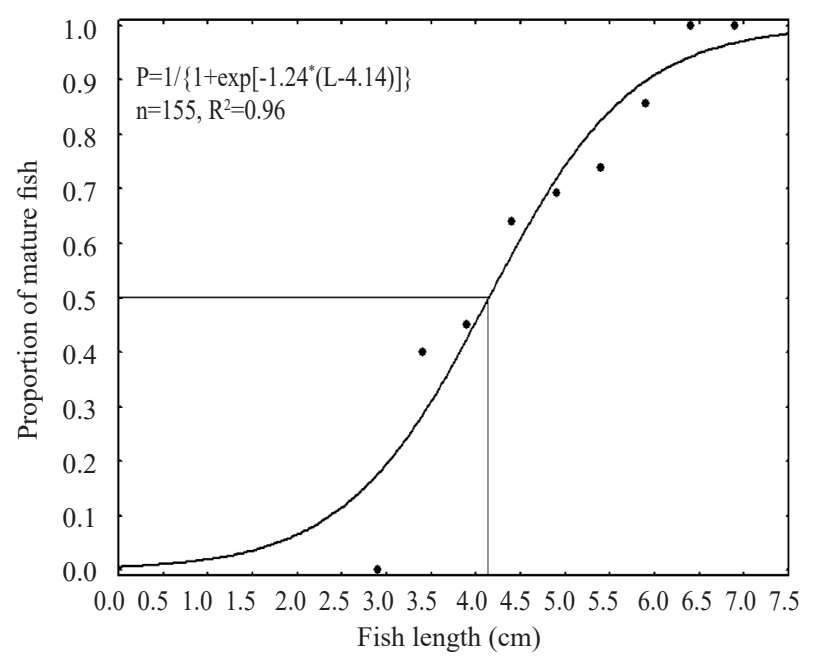

Fig. 1. Length at first maturity of Stigmatogobius pleurostigma caught from the study site 


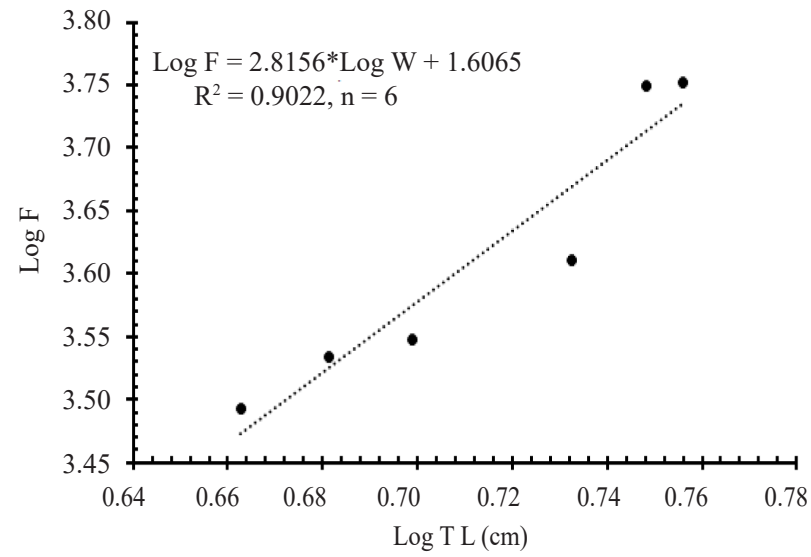

(a)

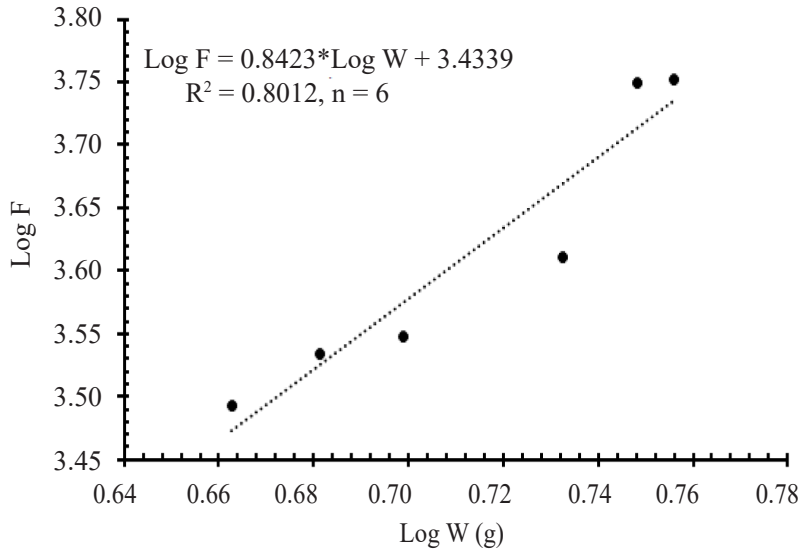

(b)

Fig. 2. Relationships between fecundity (LogF) and (a) fish total length (LogTL) and (b) body weight (LogW) of Stigmatogobius pleurostigma caught from the study site

\section{Development of ovary and testis}

The ovaries at stage I were $519 \pm 29.19 \mu \mathrm{m}$ in width, linked by connective tissue and hard to differentiate from stage I testes. Germ cells, oogonia and primary oocytes were found in ovaries at this stage (Fig. 3a). The ovarian width increased to $989.25 \pm 98.98 \mu \mathrm{m}$ in stage II when the gonad was yellowish. At this stage, two parts of each ovary were separated and easy to differentiate from testes as small oocytes were found in ovaries under a reflected light microscope. Beside primary oocytes, germ cells and oogonia, stage II ovaries also contained the primary and secondary vitellogenic oocytes (Fig. 3b). At stage III, ovarian width was $1,213.49 \pm 63.46 \mu \mathrm{m}$ and two parts of each ovary were separated and became transparent with visible orange-yellow eggs. Secondary and post-vitellogenic oocytes were mainly found in this stage (Fig. 3c). Stage IV ovaries were 1,826.97 $\pm 523 \mu \mathrm{m}$ in width and contained small whitish eggs covered by blood vessels. Post-vitellogenic oocytes with the nucleoli in the center of the nucleus were mostly found in stage IV ovaries (Fig. 3d). Ovaries reached the maximum width of $3,654.86 \pm 296.44 \mu \mathrm{m}$, became opaque and were covered by a smooth and firm membrane in stage $\mathrm{V}$.

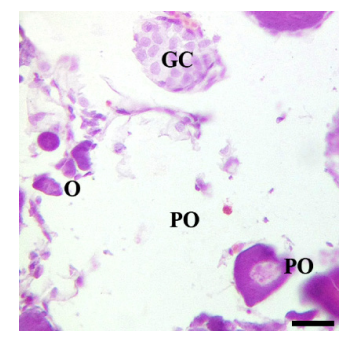

(a)

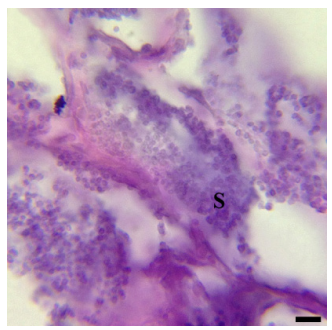

(f)

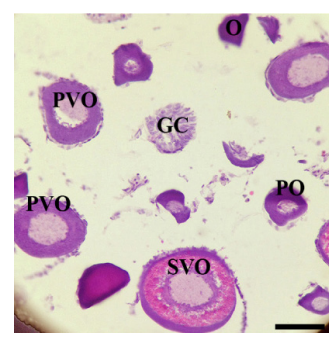

(b)

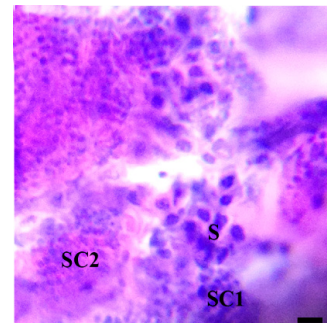

(g)

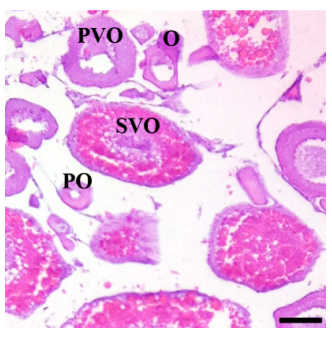

(c)

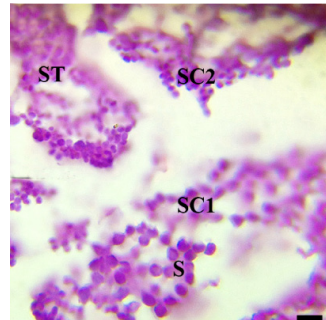

(h)

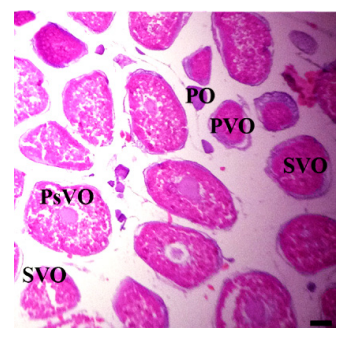

(d)

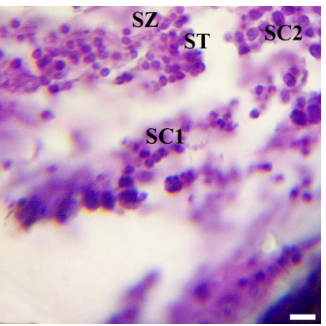

(i)

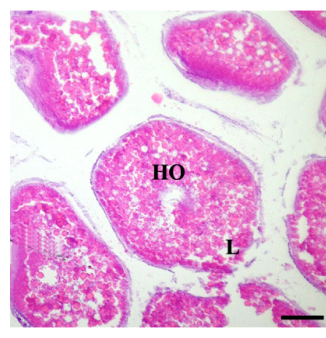

(e)

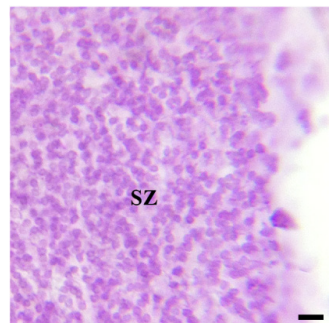

(j)

Fig. 3. Histological sections of ovary and testis of Stigmatogobius pleurostigma caught from the study site (a, b, c, d and e represent ovary stages I, II, III, IV and V; f, g, h, i and j represent testis stages I, II, III, IV and V respectively). GC: germ cells, O : oogonia, PO: primary oocyte, PVO: primary vitellogenic oocytes, SVO : secondary vitellogenic oocytes, PsVO: post-vitellogenic oocytes, HO: hydrated oocytes, L: lipid, S: spermatogonia, SC1: primary spermatocytes, SC2 : secondary spermatocytes, ST: spermatid, SZ: spermatozoa. Scale bar: Ovarian sections - $100 \mu \mathrm{m}$; Testis sections $-10 \mu \mathrm{m}$ 
At this stage, ovaries contained mostly hydrated oocytes and some secondary and post-vitellogenic oocytes (Fig. 3e). Resting ovaries (stage VI) were not encountered during the present study.

Testes were $320.83 \pm 31.26 \mu \mathrm{m}$ in width, elongated and paired in stage I and not easy to differentiate from stage I ovaries. Testes at this stage consisted mainly of spermatogonia (Fig. 3f). Testes width increased to $323.24 \pm 20.51 \mu \mathrm{m}$ in stage II and the testes were pale pinkish in colour. The number of primary and secondary spermatocytes increased and a few spermatogonia appeared in testes (Fig. 3g). At stage III, testes increased to $372.36 \pm 44.11 \mu \mathrm{m}$ in width and became translucent with smooth surface. At this stage, primary and secondary spermatocytes and a few spermatids and spermatozoa were found in the sperm ducts (Fig. 3h). Stage IV testes were $786.01 \pm 51.54 \mu \mathrm{m}$ in width and became milky in colour covered by blood vessels. In this stage, testes comprised mainly spermatids and spermatozoa in the testicular cavity and sperm ducts (Fig. 3i). Testes reached the maximum size of $1774.62 \pm 542.30 \mu \mathrm{m}$ in stage $\mathrm{V}$ and consisted of mainly mature spermatozoa (Fig. 3j). Like ovary, resting testes (stage VI) were also not found in this study.

Mature (stage IV) and ripe (stage V) ovaries and testes were found from March 2015 to November 2016 (Fig. 4). The oocyte diameter increased significantly during vetellogenesis from primary oocytes, primary, secondary and post-vitellogenic oocytes to hydrated oocytes (Table 2).

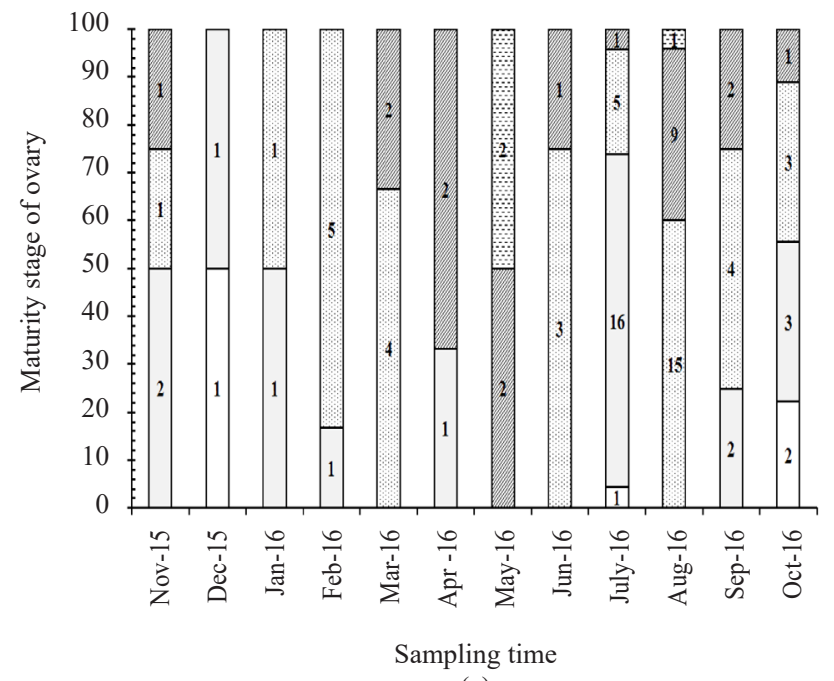

(a)
Table 2. Oocyte diameter at different maturity stages of ovary in Stigmatogobius pleurostigma

\begin{tabular}{ll}
\hline Maturity stage & Oocyte diameter, $\mu \mathrm{m}($ mean \pm SD) \\
\hline Stage I & $83.56 \pm 10.95^{\mathrm{a}}$ \\
Stage II & $139.00 \pm 18.61^{\mathrm{b}}$ \\
Stage III & $267.18 \pm 33.80^{\mathrm{c}}$ \\
Stage IV & $360.36 \pm 27.24^{\mathrm{d}}$ \\
Stage V & $401.51 \pm 28.14^{\mathrm{e}}$ \\
\hline
\end{tabular}

Values bearing different superscripts differ significantly $(\mathrm{p}<0.05)$

\section{Discussion}

According to Kovacic (2007), because of male egg-tending activity in Gobius vittatus, more females than males were caught during the spawning season. Likely, after releasing eggs into the roof of the selected caves by female $S$. sadanundio males tend eggs until hatching (Larson, 2005). The number of female S. pleugostigma in this study was significantly higher than males, whereas sex ratios of some co-occurring gobiid species such as Pseudapocryptes elongatus (Tran, 2008), Boleophthalmus boddarti (Dinh et al., 2015), Periophthalmodon schlosseri (Dinh, 2016a), Trypauchen vagina (Dinh, 2016b) and Parapocryptes serperaster (Dinh et al., 2016) are close to 1:1. This indicates that $S$. pleurostigma may share a similar reproductive behaviour with $G$. vittatus and $S$. sadanundio but different from P. elongatus (Tran, 2008), B. boddarti (Dinh et al., 2015), P. schlosseri (Dinh, 2016a), T. vagina (Dinh, 2016b) and P. serperaster (Dinh et al., 2016).

Longhurst and Pauly (1987) reported that many gobies are serial spawners depositing eggs more than once or one

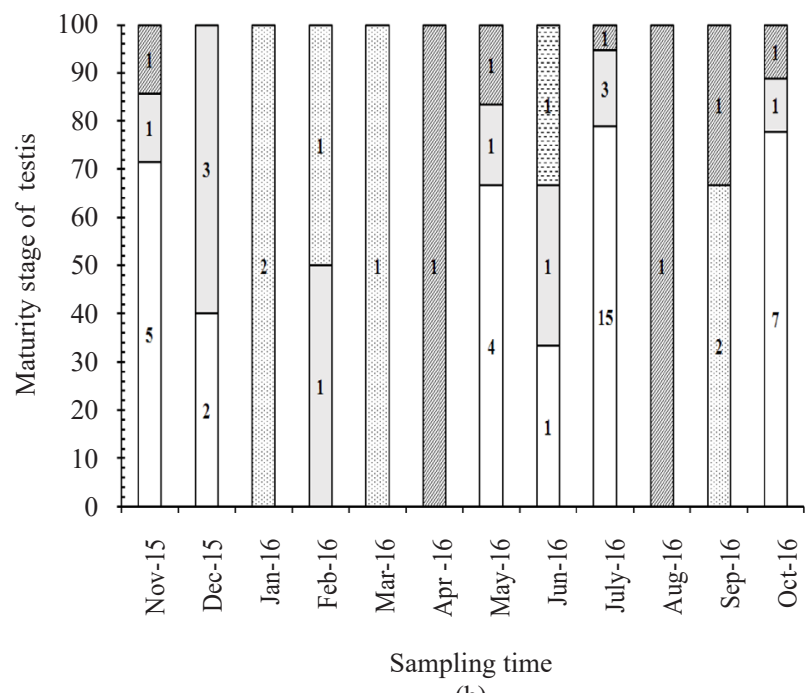

(b)

\section{$\square \mathrm{I}, \square \mathrm{II}$, 圆III, 圆 IV, 圈 V}

Fig. 4. Gonadal stage compositions of Stigmatogobius pleurostigma caught from the study site ( $\mathrm{n}=96$ for ovary and $\mathrm{n}=59$ for testis) 
time during spawning period. The present study showed that S. pleurostigma was a multiple spawner as the stage $\mathrm{IV}$ and $\mathrm{V}$ ovaries contained four oocyte types (oogonia, primary oocytes, vitellogenic and hydrated oocytes). Likely, the iteroparous types were also found in some gobies living in the same habitat, e.g., P. elongatus (Tran, 2008), B. boddarti (Dinh et al., 2015) and P. serperaster (Dinh et al., 2016). Female and male $S$. pleurostigma may release eggs and sperms from March to November due to the appearance of mature and ripe ovaries and testes during this period. In contrast, $P$. serperaster collected in the same region along with $S$. pleurostigma is a multiple spawner and deposits egg in the mid-wet season (Dinh et al., 2016). Similarly, some other co-occurring gobies such as P. elongatus (Tran, 2008) and B. bodarti (Dinh et al., 2015) also lay eggs during the main wet season (July to October).

Like other gobies, the absolute fecundity of S. pleugostigma had a positive correlation with fish total length indicating that the fecundity of this species was strongly correlated on fish size, which was also found in most gobies such as P. elongatus (Tran, 2008), B. boddarti (Dinh et al., 2015) and P. serperaster (Dinh et al., 2016). The fecundity of S. pleurostigma is higher than Neogobius melanostomus (84 to 606 eggs) in North America (Macinnis and Corkum, 2000), Crystallogobius linearis (200-700 eggs) in the Adriatic Sea (Caputo et al., 2003) and S. sadanundio (upto 1,000 eggs) (Froese and Pauly, 2017), but lower than Amblygobius phalaena $(37,000-38,000$ eggs) in Japan (Takegaki, 2000), P. elongatus (2,600-29,400 eggs) in Vietnam (Tran, 2008), B. boddarti (2,100-12,300 eggs in India and 9,800-33,800 eggs in Vietnam) (Chandran et al., 2014; Dinh et al., 2015) and P. serperaster (6,000-11,700 eggs) in Vietnam (Dinh et al., 2016). It appears that the fecundity in gobiid species varies with different geographic regions. Indeed, the fecundity of $B$. boddart $i$ is regulated by environmental factors as Chandran et al. (2014) reported its fecudity as 2,100-12,300 eggs in India while Dinh et al. (2015) reported 9,800-33,800 eggs in Vietnam

S. pleugostigma was observed to be a serial spawner releasing eggs throughout the year. This goby matured at $4.14 \mathrm{~cm}$ in total length and was found to have quite high fecundity. The understanding of size at first maturity and spawning season are helpful for local people and authorities to set the minimum legal size and time for fishing. The results of the present study fills the scientific gap in knowledge on the reproductive biology of this goby as well as to provide a better understanding of the population dynamics of the species which would help in monitoring and sustainable management of this resource in the future.

\section{Acknowledgements}

This work was supported by the Can Tho University under Grant T2016-75. We are grateful to Huynh Van Mien for fish collection.

\section{References}

Caputo, V., Mesa, M. L., Candi, G. and Cerioni, P. N. 2003. The reproductive biology of the crystal goby with a comparison to that of the transparent goby. J. Fish Biol., 62(2): 375-385.

Carleton, H. M., Drury, R. A. B. and Wallington, E. 1980. Carleton's histological technique. Oxford University Press, London, United Kingdom, 520 pp.

Chandran, R., Jaiswar, A. K., Jahageerdar, S., Poojary, N. and Chakraborty, S. 2014. A study on reproductive biology of Boleophthalmus boddarti from Mumbai region. J. Indian Fish. Ass., 41: 57-69.

Dinh, Q. M. 2016a. Growth and body condition variation of the giant mudskipper Periophthalmodon schlosseri in dry and wet seasons. J. Biol., 38(3): 352-358.

Dinh, Q. M. 2016b. Growth pattern and body condition of Trypauchen vagina in the Mekong Delta, Vietnam. J. Anim. Plant Sci., 26(2): 523-531.

Dinh, Q. M. 2017. Morphometrics and condition factor dynamics of the goby Stigmatogobius pleurostigma (Bleeker 1849) during dry and wet seasons in the Mekong Delta, Vietnam. Asian Fish. Sci., 30(1): 17-25.

Dinh, Q. M., Nguyen, T. T. G. and Nguyen, T. K. T. 2015. Reproductive biology of the mudskipper Boleophthalmus boddarti in Soc Trang. J. Biol., 37(3): 362-369.

Dinh, Q. M., Qin, J. G., Dittmann, S. and Tran, D. D. 2016 Reproductive biology of the burrow dwelling goby Parapocryptes serperaster. Ichthyol. Res., 63(3): 324-332.

Fontoura, N. F., Braun, A. S. and Milani, P. C. C. 2009. Estimating size at first maturity $\left(\mathrm{L}_{50}\right)$ from gonadossomatic index (GSI) data. Neotrop. Ichthyol., 7(2): 217-222.

Froese, R. and Pauly, D. 2017. FishBase. www.fishbase.org (Accessed 10-20 June 2017).

Komolafe, O. O. and Arawomo, G. A. O. 2007. Reproductive strategy of Oreochromis niloticus (Pisces: Cichlidae) in Opa reservoir, Ile-Ife, Nigeria. Rev. Biol. Trop., 55(2): 595-602.

Kovacic, M. 2001. The biology of Roule's goby in the Kvarner area, northern Adriatic Sea. J. Fish Biol., 59(4): 795-809.

Kovacic, M. 2007. Reproductive biology of the striped goby, Gobius vittatus (Gobiidae) in the northern Adriatic Sea. Sci. Mar., 71(1): 145-151.

Larson, H. K. 2005. A revision of the gobiid genus Stigmatogobius (Teleostei: Gobiidae), with descriptions of two new species. Ichthyol. Explor. Fres., 16(4): 347-370.

Le, T., Nguyen, M. T., Nguyen, V. P., Nguyen, D. C., Pham, X. H., Nguyen, T. S., Hoang, V. C., Hoang, P. L., Le, H. and 
Dao, N. C. 2006. Provinces and city in the Mekong Delta. Education Publishing House, Ha Noi, 575 pp.

Longhurst, A. R. and Pauly, D. 1987. Ecology of tropical oceans. Academic Press, San Diego, United States, 407 pp.

Macinnis, A. J. and Corkum, L. D. 2000. Fecundity and reproductive season of the round goby Neogobius melanostomus in the upper Detroit River. Trans. Am. Fish. Soc., 129(1): 136-144.

Metin, G., Ilkyaz, A. T., Soykan, O. and Kinacigil, H. T. 2011. Age, growth and reproduction of four-spotted goby, Deltentosteus quadrimaculatus (Valenciennes, 1837), in Izmir Bay (central Aegean Sea). Turk. J. Zool., 35(5): 711-716.

Miller, P. J. 1984. The topology of gobioid fishes. In: Potts, G. W. and Wootton, R. J. (Eds.), Fish reproduction: strategies and tactics. Academic Press, Orlando, London, United Kingdom, p. 119-153.

Takegaki, T. 2000. Monogamous mating system and spawning cycle in the gobiid fish, Amblygobius phalaena (Gobiidae). Environ. Biol. Fish., 59(1): 61-67.

Teichert, N., Valade, P., Fostier, A., Lagarde, R. and Gaudin, P. 2014. Reproductive biology of an amphidromous goby, Sicyopterus lagocephalus, in La Reunion Island. Hydrobiologia, 726(1): 123-141.

Tran, D. D. 2008. Some aspects of biology and population dynamics of the goby Pseudapocryptes elongatus (Cuvier,
1816) in the Mekong Delta. Ph. D Thesis, Universiti Malaysia, Terengganu, Malaysia, $186 \mathrm{pp}$.

Tran, D. D., Shibukawa, K., Nguyen, T. P., Ha, P. H., Tran, X. L., Mai, V. H. and Utsugi, K. 2013. Fishes of Mekong Delta, Vietnam. Can Tho University Publisher, Can Tho, 174 pp.

Trinh, K. N. and Tran, D. D. 2012. The status of capture fisheries and management of marine fishes in Soc Trang Province. Can Tho Univ. J. Sci., 24b: 46-55.

Vesey, G. and Langford, T. E. 1985. The biology of the black goby, Gobius niger L. in an English South Coast Bay. J. Fish Biol., 27(4): 417-429.

Wootton, R. J. 1990. Ecology of teleost fishes. Chapman and Hall, New York, United States, 404 pp.

Yamamoto, K. 1956. Studies on the formation of fish eggs: I. Annual cycle in the development of ovarian eggs in the flounder, Liopsetta obscura. J. Fac. Sci. Hokkaido Univ. Ser. VI. Zool., 12(3): 362-373.

Yamazaki, F. 1965. Endocrinological studies on the reproduction of the female goldfish, Carassius auratus L., with special reference to the function of the pituitary gland. Mem. Fac. Fish. Hokkaido Univ., 13(1): 1-64.

Zar, J. H. 1999. Biostatistical analysis. Prentice Hall, New Jersey, United States, 564 pp.

Date of Receipt $\quad$ : $\quad 25.02 .2017$

Date of Acceptance ： 15.12 .2017 